\title{
IMPLEMENTASI NILAI BHINNEKA TUNGGAL IKA DALAM UPAYA RESOLUSI KONFLIK ROHINGYA ${ }^{1}$
}

\author{
Achmad Zulfikar dan Sarah Nur Ramadhani \\ Program Studi Ilmu Hubungan Internasional \\ Fakultas Ilmu Sosial dan Ilmu Politik \\ Universitas Muhammadiyah Yogyakarta
}

\section{SUMMARY}

This paper analyzes conflict resolution efforts of Rohingya through instrumentalist views to implement the value of Bhinneka Tunggal Ika (Unity in Diversity) as an acknowledgment of the diversity that it is trying to convey to the government of Myanmar. Because we believe that a conflict will not occur if there is no interest from a particular party, we do an analysis of the origin of the conflict, to the dynamics of the conflict that occurred.

Using the example of the Rohingya conflict case, this paper tries to explain the role of Indonesia and the possibility of implementing Bhinneka Tunggal Ika's values to resolve the Rohingya conflict. The rise of discrimination and violence against ethnic Rohingyas based on Myanmar's Citizenship Act of 1982 is not recognized as one of the ethnic groups in Myanmar to further complicate the problem. Today hundreds of thousands of Rohingyas choose to leave their homeland and flee to other countries.

Based on the analysis in this paper, we conclude the interests of Rohingya ethnic in this conflict is the recognition by the government. Efforts to provide this recognition is to provide understanding to the Myanmar government about the importance of diversity by using local wisdom of Indonesia, Bhinneka Tunggal Ika.

Keywords: Rohingya Conflict, Unity in Diversity, Local Wisdom, Conflict Resolution

\section{RINGKASAN}

Paper ini melakukan analisis terhadap upaya resolusi konflik Rohingya melalui pandangan instrumentalis untuk mengimplementasikan nilai Bhinneka Tunggal Ika sebagai pengakuan terhadap keragaman yang berusaha disampaikan kepada pemerintah Myanmar. Karena kami meyakini bahwa suatu konflik tidak akan terjadi apabila tidak ada kepentingan dari pihak tertentu, maka kami melakukan analisa terhadap asal usul konflik, hingga dinamika konflik yang terjadi.

Dengan menggunakan contoh kasus konflik Rohingya, paper ini berusaha memaparkan peran Indonesia dan peluang implementasi nilai-nilai Bhinneka Tunggal Ika untuk menyelesaikan konflik Rohingya. Maraknya diskriminasi dan kekerasan terhadap etnis Rohingya yang berdasarkan UU Kewarganegaraan Myanmar tahun 1982 tidak diakui sebagai salah satu etnis di Myanmar makin memperkeruh masalah. Saat ini ratusan ribu etnis Rohingya memilih untuk meninggalkan tanah kelahirannya dan mengungsi ke negara lainnya.

Berdasarkan analisis dalam paper ini, kami menyimpulkan kepentingan etnis Rohingya dalam konflik ini yakni pengakuan oleh pemerintah. Upaya untuk memberikan pengakuan ini yakni memberikan pemahaman kepada pemerintah Myanmar mengenai arti pentingnya keragaman, yakni dengan menggunakan kearifan lokal Indonesia Bhinneka Tunggal Ika.

Kata Kunci: Konflik Rohingya, Bhinneka Tunggal Ika, Kearifan Lokal, Resolusi Konflik

1 Makalah diajukan pada Diskusi Ilmiah dalam Pertemuan Nasional Mahasiswa Hubungan Internasional se-Indonesia XXIV Universitas Gadjah Mada Yogyakarta yang diselenggarakan pada 25-30 November 2012. 


\section{A. PENDAhULUAN}

Konflik Rohingya merupakan salah satu pekerjaan rumah bagi ASEAN untuk menunjukkan keseriusannya dalam menciptakan perdamaian dan merangkul negara-negara di kawasan Asia Tenggara untuk mewujudkan Komunitas ASEAN 2015. Konflik yang melanda etnis Rohingya di wilayah bagian Arakan, Myanmar merupakan masalah yang telah berlarutlarut, namun tidak juga terselesaikan.

Keterbukaan Myanmar terhadap dunia Internasional beberapa tahun belakangan, ternyata membuka berbagai permasalahan internal negara yang selama ini ditutupi oleh pemerintah Myanmar. Sebagai ilmuwan Hubungan Internasional, permasalahan yang terjadi di suatu negara merupakan suatu pelajaran yang berarti dan patut untuk dicarikan jalan keluarnya. Dinamika konflik yang menimpa etnis Rohingya di Myanmar lebih banyak disebabkan hak-hak yang tidak kunjung diberikan oleh pemerintah atas keberadaan etnis Rohingya.

Kehadiran 137 etnis yang tersebar di Myanmar, menempatkannya sebagai salah satu negara dengan etnis terbesar di kawasan Asia Tenggara. Berdasarkan persebaran etnis ini diperlukan tumbuhnya nilai-nilai kebersamaan dalam keberagaman untuk mencegah konflik yang sangat potensial terjadi pada masyarakat multi-budaya. Namun demikian, akibat dominasi oleh salah satu etnis di Myanmar sehingga menyebabkan terjadinya ketimpangan antar-etnis. Ketimpangan yang paling nyata terlihat dari kebijakan pemerintah Myanmar terhadap etnis Rohingya.

Hal ini sejalan dengan pandangan Holsti, bahwa perang di penghujung abad ke dua puluh, bukan lagi tentang kebijakan luar negeri, keamanan, kehormatan, atau status. Perang tersebut adalah tentang status negara bagian, pemerintahan, dan peran serta status bangsa dan komunitas di dalam negara. ${ }^{2}$

Rumusan masalah paper kami: bagaimana implementasi nilai Bhinneka Tunggal Ika dalam upaya resolusi konflik Rohingya ? Adapun pandangan yang digunakan untuk melihat permasalahan ini lebih condong kepada pandangan instrumentalis. ${ }^{3}$ Berdasarkan pandangan ini konflik Rohingya tidak hanya disebabkan oleh perbedaan suku atau etnis, namun yang terjadi adalah kepentingan pihak-pihak tertentu yang memiliki motif terselubung dari konflik ini.

Hal ini didukung oleh hasil penelitian World Bank yang dilakukan oleh Paul Collier dan Anke Hoeffler (1998) yang menemukan bahwa konflik lebih banyak menyangkut 'keserakahan' daripada 'rasa tidak puas': pihak-pihak yang terlibat dalam konflik lebih sering mengejar keuntungan ekonomi yang timbul dari situasi perekonomian yang kacau daripada memperbaiki status kelompoknya yang hidup kekurangan. ${ }^{4}$

Selanjutnya hipotesis awal yang kami ajukan yakni, etnis Rohingya saat ini membutuhkan pengakuan dari pemerintah sebagai langkah awal untuk memberikan hak yang sama dan setara seperti etnis lainnya di Myanmar. Salah satu upaya untuk mewujudkan hal ini yakni dengan mendorong upaya-upaya pengakuan terhadap keberagaman. Salah satunya dengan mendorong Myanmar untuk mengakui keberadaan Rohingya. Sebagai tawaran kami,

\footnotetext{
${ }^{2}$ Hugh Miall, dkk, Resolusi Damai Konflik Kontemporer, Jakarta: Rajawali Pers, 2000. h. 105.

${ }^{3}$ Timo Kivimaki, Penelitian Konflik Suku dalam Masyarakat Multi Budaya dalam Dewi Fortuna Anwar, dkk (ed.), Konflik Kekerasan Internal, Jakarta: Yayasan Obor Indonesia, 2005. h. 125.

${ }^{4}$ Kivimaki, h. 124.
} 
upaya resolusi konflik terhadap etnis Rohingya dapat didorong dengan menggunakan kearifan lokal Bhinneka Tunggal Ika, yang memiliki arti "Berbeda-beda tetapi tetap satu juga" yang dimiliki dan diyakini mampu menghidupkan suasana toleransi dalam keberagaman.

Berdasarkan pandangan instrumentalis, upaya-upaya penyelesaian seperti mendorong pengakuan terhadap etnis Rohingya oleh pemerintah Myanmar sangat dimungkinkan untuk dilakukan. Salah satunya dengan implementasi nilai-nilai Bhinneka Tunggal Ika yang merupakan kearifan lokal Indonesia. Di samping itu, kedekatan Indonesia dan Myanmar dari segi geografis dan historis dapat dimanfaatkan untuk memberikan pemahaman kepada institusi pemerintahan di Myanmar untuk mengadopsi nilai keberagaman tersebut. Pada akhirnya tujuan digunakannya kearifan lokal Bhinneka Tunggal Ika diharapkan dapat membangkitkan kembali nilai-nilai keberagaman yang mungkin telah ada di Myanmar agar dijadikan upaya resolusi konflik di Rohingya.

\section{B. ASAL USUL ROHINGYA}

Rohingya adalah penduduk Muslim yang tinggal di Arakan, Myanmar. Mereka tinggal di Arakan sejak abad 7 M. Nenek moyang Rohingya berasal dari campuran Arab, Turki, Persia, Afghanistan, Bengali, dan Indo-Mongoloid. Rohingya merupakan keturunan etnis Bengali, khususnya sub-etnis Chittagonia yang tinggal di Bangladesh Tenggara. Hal itu didasarkan pada bahasa yang digunakan oleh kaum Rohingya, yaitu bahasa yang biasa dikelompokkan ke dalam bahasa Chittagonia. Bahasa tersebut sering dituturkan oleh masyarakat tenggara Bangladesh. Sedangkan bahasa yang digunakan di Myanmar kebanyakan dari rumpun Tai Kadal, Austroasiatik, dan Sino-Tibetan. ${ }^{5}$

Lebih rinci lagi disebutkan dalam The Moslem World League Journal Vol. 30, kehadiran Rohingya di Myanmar telah teridentifikasi sejak tahun 1259-1294. Dikatakan, bahwa Muslim Mongol yang memerintah sebuah kerajaan yang besar yaitu pemerintahan Kaisar Kubilai yang memerintah antara 1259-1294 yang dianggap sebagai zaman keemasan Mongol. Burma untuk pertama kalinya disebutkan dalam catatan sejarah awal Muslim. Kubilai mampu menyatukan China dan menerima upeti dari negara-negara yang tunduk dibawah kekuasaannya seperti Burma, Annam dan Champa di Indocina.

Arakan akhirnya berdiri sebagai Negara Islam yang kuat pada 1430 ketika Sultan Muhammad Caladdin Banga mengalahkan tentara Buddha Birma dalam perang. Sejak itu, 48 sultan Muslim telah memerintah di Arakan. Arakan dikenal sebagai Kerajaan Mrauk-U. Kaum Muslim Rohingya menjadi bagian dari Kerajaan Mrauk-U yang besar di Arakan, yang terletak di antara sebelah timur Kerajaan Budha Burma dan sebelah barat kerajaan Islam Mogul. Kerajaan Mrauk-U adalah contoh sempurna toleransi antara Muslim dan non-Muslim. Setelah kerajaan lemah, kaum Budha merebut kekuasaan. Meskipun Raja yang memerintah Mrauk-U kemudian pemeluk Buddha, Muslim memainkan peranan penting di lembaga pengadilan. ${ }^{6}$

\footnotetext{
${ }^{5}$ Pusat Informasi dan Advokasi Rohingya Arakan, "Rohingya 101 Data dan Fakta", [http://indonesia4rohingyadotorg.files.wordpress.com/2012/08/rohingya-101-data-dan-fakta.pdf] diakses 14 Oktober 2012.

${ }^{6}$ Nora Ahmad. 'Rohingya: The Lost Moslem Asia', The Moslem World League Journal Vol. 30, hh. 169-171
} 
Pernyataan di atas dikuatkan kembali Susetyo, menurutnya sebagai etnis Rohingya sudah hidup di Arakan, Myanmar sejak abad 7 Masehi. Tapi sebagai Muslim dengan nama kerajaan Arakan, mereka sudah mulai ada sejak tahun 1430 sampai 1784 Masehi. Jadi sekitar 3,5 abad mereka dalam kekuasaan kerajaan Muslim hingga mereka diserang oleh Kerajaan Burma, dan dianeksasi oleh Inggris. Setelah itu mereka dibawa menjadi bagian dari British India yang bermarkas di india. Kemudian berjalan bertahun-tahun lamanya sampai tahun 1940-an. Ketika Myanmar merdeka tahun 1948, ada 137 etnis yang ada di Myanmar. Sejak itupun, Myanmar tidak mengakui keberadaan mereka sebagai etnis yang ada di tanah Myanmar. Padahal ketika merdeka, Myanmar memasukkan negara bagian Arakan sebagai bagian dari Myanmar, namun setelah itu orang Rohingya atau Muslim Arakan tidak diakui sebagai etnis yang eksis di sana. Permasalahannya di sini, mereka sudah ada sebelum negara ada. Mereka dinilai minoritas dari segi warna kulit dan bahasa serta dianggap lebih dekat kepada orang Bangladesh. Walaupun mereka bukan orang Bangladesh. ${ }^{7}$

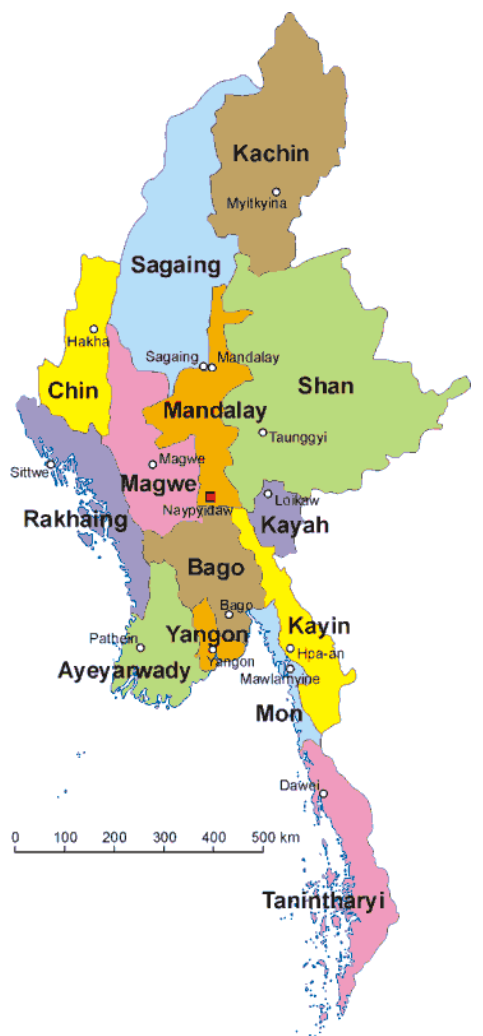

Gambar 1. Peta Wilayah Myanmar (Sumber: Wikimedia)

Keberadaan Rohingya merupakan salah satu dari 137 etnis yang ada di Myanmar. Rohingya merupakan 1 dari 8 etnis terbesar, namun menjadi minoritas di antara 7 etnis lainnya. Lebih lanjut 8 etnis tersebut dideskripsikan sebagai berikut: (a) Bamar/Birma: Masyarakat Birma merupakan dua pertiga dari total masyarakat Myanmar. Mereka semua beragama Buddha dan tinggal di sebagian besar wilayah Myanmar kecuali di bagian pedesaan, (b) Karen: Etnis ini beragama Buddha, Kristen, dan perpaduannya. Mereka

\footnotetext{
${ }^{7}$ Pizaro, "Heru Susetyo: Muslim Rohingya Sudah Ada Sebelum Myanmar Ada" [http://www.hidayatullah.com/read/23932/26/07/2012/heru-susetyo:-muslim-rohingya-sudah-ada-sebelummyanmar-ada.html] diakses 10 Oktober 2012.
} 
menghuni pegunungan yang dekat dengan perbatasan Thailand, (c) Kayah: suku ini berkerabat dengan etnis Thai. Suku Kayah merupakan irisan dari suku Karenni dan suku Karen, (d) Arakan: etnis ini merupakan nama lain dari Rakhine. Pada umumnya, masyarakat Arakan beragama Buddha. Mereka tinggal di perbukitan Myanmar Barat, (e) Mon: merupakan etnis yang beragama Buddha yang menghuni kawasan selatan dekat dengan perbatasan Thailand, (e) Kachin: suku ini juga tersebar di Cina dan India. Kebanyakan dari mereka beragama Kristen, (f) Chin: suku ini beragama mayoritas Kristen dan tinggal di dekat perbatasan India, dan (e) Rohingya: etnis yang beragama Islam ini tinggal di bagian utara Rakhine/Arakan. Saat ini kebanyakan mereka telah mengungsi ke Bangladesh atau Thailand. ${ }^{8}$

Menurut Jacques P. Leider, seorang sejarawan menyatakan pada abad ke-18 ditemukan adanya masyarakat muslim di Arakan yang menamakan dirinya "Rooinga" pada catatan Francis Buchanan-Hamilton dari Inggris. Ada pendapat yang mengatakan bahwa kata tersebut berasal dari kata "rahma" (rahmat) dalam bahasa Arab dan "rogha" (perdamaian) dalam bahasa Pasthun. Dan ada pula pendapat yang mengatakan bahwa kata tersebut dari sebuah tempat di wilayah Ruhadi Afghanistan yang disinyalir sebagai tempat asal Rohingya. ${ }^{9}$

\section{DINAMIKA KONFLIK ROHINGYA}

Menurut Susetyo, sejak sebelum Myanmar merdeka, tahun 1942, sudah ada aksi kekerasan kepada orang Rohingya. Ribuan orang Rohingya dibunuh. Baik oleh negara maupun etnis mayoritas, karena mereka dianggap minoritas dan bukan bagian dari Myanmar. Kemudian berulang terus setelah Myanmar merdeka, ada operasi-operasi tentara yang sering kali dilakukan sejak tahun 1950-an. Yang paling mengerikan adalah $\mathrm{Na}$ Sa Ka Operation di antaranya dengan metode kekerasan, pengusiran, Burmanisasi, bahkan halangan untuk menikah. Tindakan agresif oleh negara kemudian berkembang menjadi kejahatan sipil antar orang Rohingya dengan orang Arakan lainnya yang non-Muslim. Susetyo menyatakan bahwa orang Arakan non-Muslim sebenarnya cukup peaceful (tenang). Orang Buddha itu peaceful, mereka anti kekerasan. Menurutnya, mereka terprovokasi oleh media, pemerintah, dan agitasi dari tokoh-tokoh yang tidak bertanggung jawab sehingga timbul kekerasan. Konflik atas dua etnis itu jarang terjadi. Yang terjadi biasanya adalah konflik negara dengan orang Rohingya. Tapi sekarang jadi konflik horizontal. Dan Susetyo meyakini ada kepentingan di balik kekeruhan masalah itu. ${ }^{10}$

Untuk mengurai konflik Rohingya yang terjadi maka digunakan bagan berikut ini, agar lebih mudah memahami permasalahan yang dialami oleh etnis Rohingya.

\footnotetext{
${ }^{8}$ Yoan Indranastiti, “Sejarah Negara Myanmar”, [http://yoanindranastiti.wordpress.com/2012/01/27/sejarahnegara-myanmar/] diakses 14 Oktober 2012.

9 Totok Suhardijanto, "Mengenal Etnis Rohingya dari Sudut Pandang Sejarah", [http://www.mizan.com/news_det/mengenal-etnis-rohingya-dari-sudut-pandang-sejarah.html] diakses 14 Oktober 2012.

${ }^{10}$ Pizaro, diakses 10 Oktober 2012.
} 


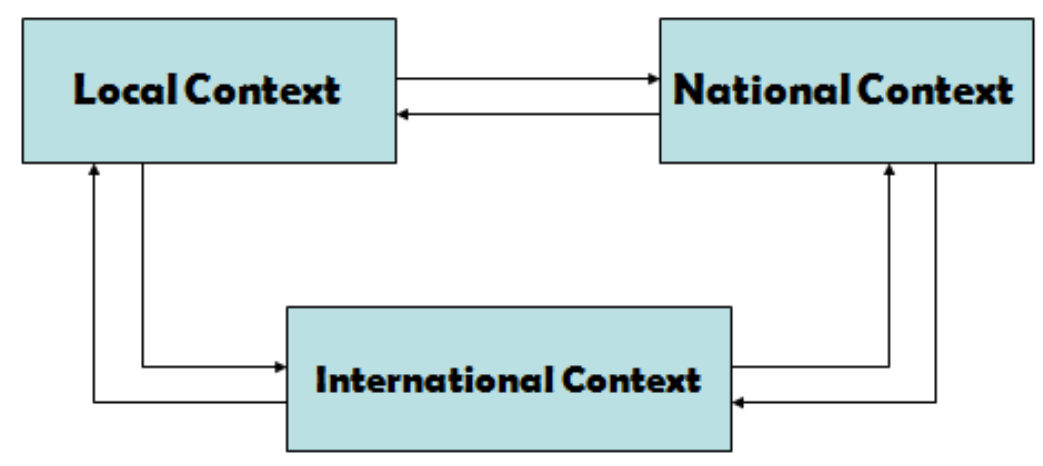

Bagan 1. Hubungan Antar Situasi dalam Konflik Etnis (Sugito: 2012)

Berdasarkan bagan di atas, maka kita dapat mengurai konflik Rohingya berdasarkan konteksnya, baik di tingkatan lokal, nasional, maupun internasional. Konteks lokal, Rohingya telah mengalami diskriminasi oleh etnis mayoritas, hal ini berkembang menjadi diskriminasi oleh etnis lainnya yang tinggal di dalam satu wilayah yakni Arakan. Diskriminasi ini berujung pada tidak diakuinya etnis Rohingya, sehingga hak-hak sebagai warga negara Myanmar tidak di dapatkan bahkan diabaikan.

Konteks nasional, pemerintah Myanmar tidak mengakui kewarganegaraan etnis Rohingya karena menganggap kelompok ini bukan merupakan kelompok etnis yang sudah ada di Myanmar sebelum kemerdekaan Myanmar pada 1948. Hal ini ditegaskan kembali oleh Presiden Myanmar, Thein Sein, dalam Al Jazeera, 29 Juli 2012 bahwa Myanmar tak mungkin memberikan kewarganegaraan kepada kelompok Rohingya yang dianggap imigran gelap dan pelintas batas dari Bangladesh itu. Ditambah lagi pernyataannya bahwa 'Rohingya are not our people and we have no duty to protect them'. Selanjutnya, ia menginginkan supaya etnis Rohingya dikelola oleh UNHCR saja atau ditampung di negara ketiga yang mau menampungnya. Ia juga menyebut etnis Rohingya di Arakan sebagai 'a threat to national security'. ${ }^{11}$

Disamping itu, kebijakan perundang-undangan Myanmar meniadakan Rohingya sebagai etnis yang diakui di Myanmar. Kebijakan ini tertuang dalam UU Kewarganegaraan Myanmar tahun 1982, hal ini juga berarti meniadakan hak etnis Rohingya dalam hal: (a) Hak untuk bebas bergerak dan berpindah tempat, (b) Hak untuk menikah dan memiliki keturunan, (c) Hak atas Pendidikan, (d) Hak untuk berusaha dan berdagang, (e) Hak untuk bebas berkeyakinan dan beribadah, dan (f) Hak untuk bebas dari penyiksaan dan kekerasan. ${ }^{12}$

Berdasarkan paparan di atas, dapat diidentifikasi strategi yang digunakan negara untuk menghadapi konflik ini lebih cenderung ke arah konfrontasi dibandingkan akomodasi. Adapun bentuk-bentuk konfrontasi dari cara-cara yang paling lunak sampai paling keras, antara lain: (1) asimilasi, (2) cultural genocide, (3) forced migration (deportasi), (4) ethnic cleansing, (5) relocation, (6) replacement, dan (7) genocide. ${ }^{13}$

\footnotetext{
${ }^{11}$ Al Jazeera, "Why is the world ignoring Myanmar's Rohingya?", [http://www.aljazeera.com/programmes/insidestory/2012/07/201272383656931979.html] diakses 17 Oktober 2012.

${ }^{12}$ Genocide Watch, "Genocide Emergency: Western Myanmar, Rakhine State: The Rohingya", [http://www.genocidewatch.org/myanmar.html] diakses 20 Oktober 2012.

${ }^{13}$ Sugito, Ethnic and Internal Conflict [Bahan Ajar] Yogyakarta: Jurusan Ilmu Hubungan Internasional Universitas Muhammadiyah Yogyakarta, 2012.
} 
Fakta pada penjelasan sebelumnya menunjukkan bahwa sejak 1942 telah terjadi usaha negara dengan melakukan kekerasan terhadap etnis Rohingya sebagai upaya untuk mengusir etnis tersebut dari wilayah Arakan. Hal ini berlanjut dengan usaha negara melalui kebijakan perundang-undangan tahun 1982 dengan tidak mengakui Rohingya sebagai warga negara. Usaha negara ini berlangsung hingga saat ini dengan tetap menerapkan kebijakan perundangundangan tersebut dan menggantungkan nasib etnis Rohingya. Usaha negara ini, berdasarkan strategi konfrontasi tergolong ke dalam tingkat ke-3 yakni forced migration (deportasi). Penggolongan ini didasarkan pada aspek yang ditimbulkan sebagai akibat dari usaha-usaha negara yang telah dilakukan yakni terusirnya etnis Rohingya dari asalnya yang menjadikannya sebagai pengungsi.

Sedangkan strategi etnis Rohingya yang selama ini mengalami penindasan dan diskriminasi cenderung menerima dengan tindakan konfrontasi negara daripada menolak. Hal ini terlihat dari upaya-upaya yang dilakukan oleh etnis ini baik dari dalam maupun luar negeri. Salah satunya dengan perjuangan yang ditunjukkan oleh Organisasi Nasional Rohingya Arakan (ARNO) yang menyusun piagam penentuan nasib dengan pernyataan sebagai berikut: (1) bahwa perjuangan ARNO adalah untuk mencapai hak penentuan nasib sendiri bagi rakyat Rohingya, (2) bahwa junta militer Burma telah terlibat dalam tindakan penganiayaan atas agama sebagai alat Burmanisasi negara, (3) bahwa komunitas Muslim di seluruh Burma juga mengalami penindasan dan penganiayaan, (4) bahwa sekitar setengah penduduk kami telah diusir dari negara dalam rangka untuk memusnahkan orang-orang Rohingya, (5) bahwa kita akan mengorganisir, memberikan inspirasi dan mengaktifkan seluruh rakyat Rohingya, terlepas dari tempat tinggal dan pengungsian mereka sekarang, (6) bahwa kita akan melaksanakan semua program yang mungkin perlu dari waktu ke waktu untuk mengangkat harkat orang Rohingya di bidang sosial budaya, ekonomi, pendidikan dan teknis, dan (7) bahwa rezim militer sedang mencoba untuk melenyapkan dan menghapus entitas muslim di Arakan dengan mendistorsi fakta sejarah, menghancurkan peninggalan arkeologi, masjid, sekolah, kuil dan kuburan di Arakan dan Birma untuk menghapus warisan budaya Islam Arakan. ${ }^{14}$

ARNO menegaskan bahwa orang-orang Rohingya tidak memusuhi kelompok etnis atau agama tertentu dan akan bekerja sama dengan kekuatan demokratik. ARNO menginginkan pembangunan kesejahteraan masyarakat berdasarkan atas kesetaraan, kebebasan, demokrasi, hak asasi manusia dan kebebasan bagi semua orang, tanpa membedakan ras, kulit dan agama. ${ }^{15}$

Namun demikian strategi yang dilakukan oleh etnis Rohingya ini bersifat dinamis, dalam artian dapat berubah-ubah sesuai dengan dinamika konflik yang terjadi. Organisasi pergerakan Rohingya seperti ARNO dapat sewaktu-waktu memobilisasi etnis Rohingya untuk melakukan pemberontakan, namun hal tersebut tidak dapat dipastikan mengingat kondisi etnis Rohingya terdiaspora ke berbagai negara seperti: Indonesia, Malaysia, Bangladesh, dan negara lainnya.

Secara internasional, dukungan yang diperoleh oleh etnis Rohingya telah mulai berdatangan baik dari PBB (Perserikatan Bangsa-Bangsa) dan Institusi yang bernaung

\footnotetext{
${ }^{14}$ Ahmad, hh. 176-180.

15 Ahmad, hh. 176-180.
} 
dibawahnya, Bulan Sabit Merah Internasional, organisasi non-pemerintah, maupun negaranegara anggota ASEAN seperti: Indonesia, Thailand, dan Malaysia yang berperan aktif dalam menyuarakan kepedulian untuk penyelesaian konflik ini.

Namun demikian, peran ASEAN secara institusional sangat minim, walaupun ASEAN mempunyai badan HAM yang seharusnya bisa menangani konflik Rohingya. Badan tersebut adalah ASEAN Intergovermental Comisssion on Human Right (AICHR). AICHR merupakan komisi antar-pemerintah ASEAN untuk hak asasi manusia. Badan ini menangani kasus pelanggaran hak asasi manusia seperti yang terjadi pada Rohingya. Tetapi, disini peran ASEAN sangat kurang dikarenakan ASEAN tak mempunyai kedaulatan untuk ikut campur permasalahan Rohingya. ASEAN tidak bisa turun tangan secara utuh di samping itu dari pihak Myanmar sendiri menolak untuk diberi bantuan. Maka disini ASEAN hanya bisa mengawasi.

\section{BHINNEKA TUNGGAL IKA DAN PENGAKUAN TERHADAP KERAGAMAN}

Bhinneka Tunggal Ika merupakan semboyan nasional Indonesia. Kalimat tersebut berasal dari terjemahan bahasa Jawa Kuno yang memiliki arti Kebersamaan dalam Keragaman (Unity in Diversity). ${ }^{16}$ Semboyan ini juga diletakkan dalam simbol negara yakni Garuda Pancasila yang tertulis pada pita yang dicengkram oleh cakar Garuda. Secara spesifik semboyan ini disebutkan dalam pasal 36 A Undang-Undang Dasar Republik Indonesia yaitu "Lambang negara ialah Garuda Pancasila dengan semboyan Bhinneka Tunggal Ika".

Lebih lanjut, Bhinneka Tunggal Ika merupakan kutipan dari karya sastra Jawa Kuno yang ditulis oleh Mpu Tantular dalam rezim kerajaan Majapahit yang diperkirakan berada pada abad ke-14. Kutipan tersebut berasal dari kanto 139 bait 5 sebagai berikut:

Rwâneka dhâtu winuwus Buddha Wiswa,

Bhinnêki rakwa ring apan kena parwanosen,

Mangka ng Jinatwa kalawan Siwatatwa tunggal,

Bhinnêka tunggal ika tan hana dharma mangrwa.

Terjemahan

Dikatakan bahwa Buddha dan Shiva merupakan dua zat yang berbeda.

Mereka memang berbeda, namun namun bagaimana mungkin untuk mengenali perbedaan mereka dalam sekejap,

karena kebenaran Jina (Buddha) dan kebenaran Shiva adalah satu.

Mereka memang berbeda, tetapi mereka dari jenis yang sama, karena tidak ada dualitas dalam Kebenaran. ${ }^{17}$

Dari pemaparan di atas menunjukkan bahwa nilai-nilai kearifan lokal Bhinneka Tunggal Ika berasal dari kebudayaan Jawa Kuno yang kemudian diadopsi ke dalam semboyan nasional. Dari nilai-nilai tersebut setidaknya dapat ditangkap semangat untuk melihat persamaan dari keduanya dibandingkan perbedaan yang pada akhirnya akan menimbulkan konflik. Pada realitasnya, nilai Bhinneka Tunggal Ika telah menunjukkan

\footnotetext{
${ }^{16}$ Soewito Santoso. Sutasoma: a Study in Old Javanese Wajrayana. New Delhi: International Academy of Culture, 1975. h. 578.

${ }^{17}$ Teks ini diterjemahkan dengan sedikit perubahan oleh Dr. Soewito Santoso.
} 
kekuatannya untuk menyatukan berbagai macam etnis dan aliran kepercayaan untuk bergotongroyong membangun Indonesia.

\section{E. PERAN INDONESIA DALAM UPAYA RESOLUSI KONFLIK ROHINGYA}

Semboyan Bhinneka Tunggal Ika merupakan hal yang tak terpisahkan dari Indonesia. Hidup berdampingan satu sama lain yang kita rasakan saat ini tidak terlepas dari kuatnya nilai itu hidup dalam kehidupan bermasyarakat kita dan hidup dalam budaya-budaya setempat sebagai nilai yang dapat diterima, dan dijalankan oleh setiap orang.

Peran Indonesia menjadi sangat penting dibahas dalam hal ini. Karena pihak Indonesia yang akan membawa nilai-nilai Bhinneka Tunggal Ika tersebut untuk disepahamkan dengan pemerintah Mynamar, baik secara institusi negara, organisasi nonpemerintah, maupun individu. Kami optimis dengan masuknya nilai Bhinneka Tunggal Ika dalam sendi kehidupan bernegara di Myanmar dapat mengubah persepsi pemerintah Myanmar terhadap keberadaan etnis Rohingya serta dapat membawa angin perubahan bagi nasib mereka.

Peluang Indonesia sangat besar untuk masuk dalam sistem di Myanmar secara bilateral. Namun secara bersama-sama dengan negara ASEAN yang lain peluangnya sangat kecil karena prinsip yang diakui dalam perjanjian treaty of amity and cooperation (TAC) menegaskan bahwa "tidak melakukan intervensi urusan dalam negeri negara lain"18.

Semakin kecilnya peluang usaha ASEAN secara institusional untuk menyelesaikan konflik Rohingya terlihat dari penolakan perwakilan Myanmar ketika Menteri Luar Negeri Indonesia Marty Natalegawa, Menteri Luar Negeri Kamboja Hor Namhong dan Surin dalam pertemuan ASEAN Day (2012) mendiskusikan keinginan mereka untuk mengangkat isu Rohingya ke KTT ASEAN.

Dari diskusi komisi HAM (International Humanitarian Action Forum 2012), diungkapkan oleh Irnawati, peneliti IISIP Jakarta. Saat kasus Rohingya akan dibawa ke tingkat ASEAN untuk dijadikan bahan topik diskusi, Myanmar menolak. Apa yang membuat Myanmar menolak bantuan dari ASEAN? Padahal dengan jelas mereka sangat membutuhkan bantuan dari negara-negara tetanggganya. Myanmar menolak diadakannya diskusi untuk pembicaraan masalah Rohingya dikarenakan mereka ingin menyelesaikan masalah domestik mereka secara mandiri. Mereka tidak ingin masalah ini di bawa sampai ke tingkat ASEAN. Dan mereka berpendapat, tercapainya kesepakatan akan dibawanya permasalahan Rohingya, hanya didasarkan oleh 3 suara anggota negara. ${ }^{19}$

Di samping itu, Indonesia dan Myanmar mempunyai banyak kesamaan yang terdapat di dalam negaranya. Indonesia memiliki beranekaragam suku dan etnis yang berbeda-beda, di samping itu memiliki pembagian wilayah yang terdiaspora berdasarkan etnisitas seperti Kalimantan, Sumatera, Jawa, Sulawesi, maupun Papua. Begitupun dengan Myanmar yang memiliki ratusan etnis, dan memiliki pembagian wilayah yang cukup banyak.

Kesamaan Indonesia dan Myanmar juga dapat dilihat dari pengalaman historis dipimpin oleh sistem pemerintahan yang tertutup. Sistem tertutup yang dimaksud ketika

\footnotetext{
${ }^{18}$ Hilton Tarnama Putra dan Eka An Aqimuddin. Mekanisme Penyelesaian Sengketa di ASEAN: Lembaga dan Proses. Yogyakarta: Graha Ilmu, 2011. h. 44.

${ }^{19}$ Tercapainya kesepakatan didasarkan oleh 3 suara anggota negara (Diskusi Komisi HAM International Humanitarian Action Forum, 2012).
} 
Indonesia berada di era pemerintahan Soeharto, dimana kebebasan masyarakat dikekang oleh pemerintah. Begitupun kondisi yang dialami oleh Myanmar pada saat dikuasai oleh Junta Militer.

Salah satu dasar peran Indonesia terhadap upaya mewujudkan perdamaian dan resolusi konflik di Rohingya berasal dari amanat pembukaan Undang-Undang Dasar Republik Indonesia yang berbunyi sebagai berikut: "Kemudian daripada itu untuk membentuk suatu pemerintahan Indonesia yang melindungi segenap bangsa Indonesia dan seluruh tumpah darah Indonesia dan untuk memajukan kesejahteraan umum, mencerdaskan kehidupan bangsa, dan ikut melaksanakan ketertiban dunia yang berdasarkan kemerdekaan, perdamaian abadi, dan keadilan sosial..."

Pada pembukaan UUD RI di atas terdapat bagian kalimat yang menyatakan "ikut melaksanakan ketertiban dunia yang berdasarkan kemerdekaan, perdamaian abadi, dan keadilan sosial". Kalimat ini mengungkapkan bahwa Indonesia memiliki kewajiban secara aktif untuk berpartisipasi dalam forum internasional untuk mewujudkan kemerdekaan bagi pihak yang ditindas seperti yang dialami oleh Rohingya. Perdamaian akan tercipta bilamana manusia hidup berdampingan satu sama lain, sedangkan prinsip keadilan sosial memiliki arti ketika Indonesia harus berpihak terhadap kebenaran yang hakiki.

Hal ini semakin diperkuat oleh pernyataan presiden Republik Indonesia Susilo Bambang Yudhoyono yang menyatakan: "The world is changing, but we must maintain the fundamental principle introduced by our founding fathers: Bhinneka Tunggal Ika. There is no reason not to respect each other, maintain harmony and uphold tolerance". ${ }^{20}$

Dari penjelasan di atas, maka dapat disimpulkan Indonesia telah ditempatkan pada posisi yang strategis untuk turut andil dalam penyelesaian konflik di Rohingya. Dengan membawa nilai Bhinneka Tunggal Ika sebagai upaya resolusi konflik Rohingya, diharapkan dapat berkontribusi dengan maksimal.

\section{F. IMPLEMENTASI NILAI BHINNEKA TUNGGAL IKA DALAM UPAYA RESOLUSI KONFLIK ROHINGYA}

Pada bagian ini kami akan menggunakan bagan Fisher untuk menjelaskan posisi nilai Bhinneka Tunggal Ika sebagai upaya resolusi konflik Rohingya. Bagan "bawang” Fisher terdiri atas tiga bagian yakni posisi (apa yang diinginkan), kepentingan (apa yang benar-benar diinginkan), dan kebutuhan atau nilai (apa yang harus didapatkan). ${ }^{21}$ Lebih jelasnya diungkapkan dalam bagan berikut:

\footnotetext{
${ }^{20}$ Bagus BT Saragih, "SBY Reminds of Importance of 'Bhinneka Tunggal Ika", [http://www.thejakartapost.com/news/2012/08/02/sby-reminds-importance-bhinneka-tunggal-ika.html] diakses 17 Oktober 2012.

${ }^{21}$ Simon Fisher (ed.), Working with Conflict: Skills and Strategies for Action, United Kingdom: Zed Books, 2000. h. 27.
} 


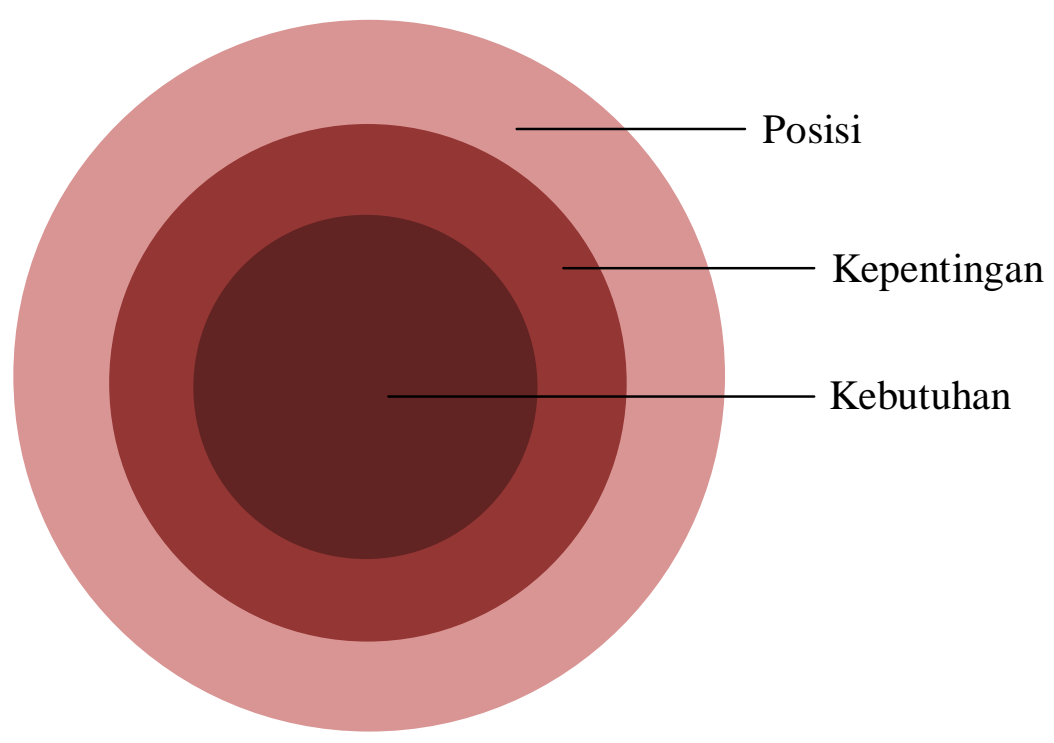

Bagan 2. Metode "Bawang” Fisher

Berdasarkan bagan di atas maka dapat dibuat tabel untuk memudahkan identifikasi guna mencari solusi yang tepat untuk masuknya kearifan lokal Bhinneka Tunggal Ika dalam upaya resolusi konflik.

\begin{tabular}{|l|l|l|}
\hline Pihak Berkonflik & \multicolumn{1}{|c|}{ Pemerintah Myanmar } & \multicolumn{1}{|c|}{ Etnis Rohingya } \\
\hline Posisi & $\begin{array}{l}\text { Rohingya are not our people and } \\
\text { we have no duty to protect them }\end{array}$ & $\begin{array}{l}\text { Mencapai hak penentuan } \\
\text { nasib sendiri }\end{array}$ \\
\hline Kepentingan & $\begin{array}{l}\text { Pemerintah Myanmar } \\
\text { menginginkan } \\
\text { meninggalkan wilayah Arakan, } \\
\text { bahkan meninggalkan Myanmar }\end{array}$ & $\begin{array}{l}\text { Ingin mendapatkan } \\
\text { pengakuan dari negara } \\
\text { sebagai etnis yang } \\
\text { mempunyai hak yang sama } \\
\text { dengan etnis lainnya di } \\
\text { Myanmar }\end{array}$ \\
\hline Kebutuhan & - & $\begin{array}{l}\text { Rohingya merupakan muslim } \\
\text { yang telah menetap di } \\
\text { Arakan sejak abad ke-7 } \\
\text { masehi aban }\end{array}$ \\
\hline
\end{tabular}

Tabel 1. Identifikasi Konflik Rohingya

Dari paparan di atas, dapat dilihat pada bagian kepentingan di sisi etnis Rohingya, mereka menekankan pada aspek pengakuan dari pemerintah. Sedangkan di sisi pemerintah Myanmar mendesak etnis Rohingya untuk meninggalkan Myanmar. Akibat dari kebijakan tersebut, etnis Rohingya yang semula mendiami wilayah Arakan perlahan-lahan akan terusir dengan berbagai cara yang dilakukan pemerintah.

Pada dasarnya suatu konflik bisa diselesaikan pada bagian kepentingan, dengan asumsi kepentingan ini merupakan hal yang diinginkan oleh kedua belah pihak, serta 
kekuatan internasional berpengaruh pada dinamika dan manajemen konflik. ${ }^{22}$ Berangkat dari asumsi tersebut maka hubungan bilateral antar-negara dapat mempengaruhi kepentingan negara yang berkonflik terhadap permasalahan yang dihadapi. Adapun cara yang ditempuh yakni win-win solution maupun kompromi.

Berdasarkan analisa kami, win-win solution dapat diwujudkan dengan mengintensifkan hubungan Indonesia-Myanmar melalui pihak-pihak Indonesia yang melakukan kerjasama baik secara institusi pemerintah, organisasi non-pemerintah, maupun individu. Intesifikasi hubungan ini dimaksudkan untuk mendorong pengakuan pemerintah terhadap etnis Rohingya dengan memasukkan nilai Bhinneka Tunggal Ika untuk dipahami oleh pemerintah Myanmar sebagai nilai pemersatu di Indonesia.

Untuk mewujudkan pengakuan terhadap keragaman di Myanmar tidaklah mustahil atau mengada-ada. Karena pada dasarnya nilai-nilai ini telah hadir dalam semangat pendirian Myanmar. Hal ini ditunjukkan dari pernyataan Jendral Aung San sebagai berikut: Burma is a multi-cultural society with multi-ethnicities. During its independence a feeling of awareness for an ethnic togetherness and comprehensive identity to form joint feelings for tranquillity and safety developed. On the basis of the agreed upon principle of 'unity in diversity', articulated by the father of the nation General Aung San, the 'Union of Burma' came into existence on January 4, $1948 .^{23}$

Apabila Myanmar telah mengakui keberadaan etnis Rohingya, hal ini berarti keinginan negara untuk mengusir mereka dari Myanmar sudah tidak lagi dilakukan. Di samping itu juga mengakomodasi keinginan dari etnis Rohingya atas pengakuan mereka sebagai bagian dari Myanmar.

Berdasarkan hasil penelitian Kivimaki (2000), kemauan negara untuk menghargai kaum minoritas dapat membuat angka perang suku ataupun konflik internal menjadi turun. Pemerintah harus menetapkan undang-undang tentang sikap saling menghargai antara kaum minoritas dan mayoritas. Karena masyarakat yang sejahtera merupakan salah satu faktor dari kemajuan negara. $^{24}$

Namun demikian, proses untuk mewujudkan hal ini membutuhkan waktu. Berikut diuraikan tahapan untuk melaksanakan resolusi konflik antara lain: Tahap pertama, masih didominasi oleh strategi militer yang berupaya untuk mengendalikan kekerasan bersenjata yang terjadi. Tahap kedua, memiliki orientasi politik yang bertujuan untuk memulai proses re-integrasi elit politik dari kelompok-kelompok yang bertikai. Tahap ketiga lebih bernuansa sosial dan berupaya untuk menerapkan problem-solving approach. Tahap keempat memiliki nuansa kultural yang kental karena tahap ini bertujuan untuk melakukan perombakanperombakan struktur sosial budaya yang dapat mengarah kepada pembentukan komunitas perdamaian yang langgeng. ${ }^{25}$

Dari empat tahapan di atas, masuknya nilai Bhinneka Tunggal Ika seperti yang telah dijelaskan sebelumnya dimasukkan dalam tahap kedua yang mempunyai orientasi politik.

\footnotetext{
${ }^{22}$ Sugito [Bahan Ajar].

${ }^{23}$ Nurul Islam, "Rohingya Tangled in Burma Citizenship Politics",

[http://indonesia4rohingya.org/2012/08/12/rohingya-tangled-in-burma-citizenship-politics/] diakses 16 Oktober 2012.

${ }^{24}$ Kivimak, hh. 120-122

${ }^{25}$ Akhmad Jenggis P. 10 Isu Global di Dunia Islam. Yogyakarta: NFP Publishing, 2012. hh. 91-92.
} 
Dipaparkan oleh Jenggis (2012), ketika de-eskalasi politik sudah terjadi, dan intervensi kemanusiaan dilakukan maka dapat dilakukan juga usaha untuk membuka peluang (entry) diadakannya negosiasi antar-elit. Pada tahap ini kental dengan orientasi politik yang bertujuan untuk mencari kesepakatan politik (political settlement) antara aktor konflik. Selain itu, nilai ini juga berperan penting dalam tahap keempat yakni peace-building. Peran Bhinneka Tunggal Ika dalam tahapan ini yakni diadopsinya nilai toleransi dan pengakuan terhadap keragaman ke dalam nilai-nilai setempat sehingga dijadikan pegangan bersama bagi etnis-etnis yang beranekaragam tersebut.

\section{G. KESIMPULAN}

Berdasarkan pemaparan kami dapat disimpulkan beberapa poin antara lain. Rohingya merupakan penduduk asli wilayah Rakhine sejak abad ke 7 masehi. Namun berbagai upaya dilakukan oleh pemerintah Myanmar baik secara kekerasan maupun politik untuk mengusir etnis Rohingya dari tempat tinggalnya di wilayah bagian Arakan. Dasar bagi pemerintah untuk mengusir Rohingya karena mereka tidak diakui sebagai warga negara sebagaimana aturan UU Myanmar tahun 1982 tentang Kewarganegaraan.

Akibatnya ratusan ribu etnis Rohingya terusir ke negara-negara lain seperti: Indonesia, Malaysia, Thailand, dan Bangladesh. Sebagai upaya untuk menyelesaikan konflik di Myanmar, maka peran Indonesia sangat dibutuhkan. Kedekatan Indonesia-Myanmar dari segi penduduk, keragaman, hingga sejarah membuat posisi Indonesia lebih mudah diterima.

Nilai keragaman dan toleransi yang termaktub dalam Bhinneka Tunggal Ika merupakan salah satu solusi bagi pengakuan terhadap keragaman di Myanmar. Hal ini bukan berarti menggunakan semboyan tersebut dalam sistem kebudayaan di Myanmar, namun menjadikan kearifan lokal tersebut sebagai awal untuk menyemai nilai-nilai keragaman dan toleransi di Myanmar yang telah lama terkubur dalam sejarah Myanmar.

Namun demikian nilai Bhinneka Tunggal Ika memerlukan waktu yang tepat untuk masuk sebagai upaya resolusi konflik Rohingya. Seperti yang telah dijelaskan pada bagian sebelumnya, tahapan resolusi konflik terdiri dari runtutan panjang yang setahap demi setahap harus dijalankan. Apabila tiba waktunya kearifan lokal ini akan mulai memasuki sistem di Myanmar. Di samping itu, dorongan dari pihak-pihak Indonesia yang melakukan hubungan dengan Myanmar seperti organisasi non-pemerintah, maupun individu diharapkan dapat turut andil untuk menyemai nilai Bhinneka Tunggal Ika di Myanmar.

\section{BIBLIOGRAPHY}

\section{Buku}

Anwar, Dewi Fortuna dkk. (ed.) Konflik Kekerasan Internal. Jakarta: Yayasan Obor Indonesia, 2005.

Association of Southeast Asian Nations. Roadmap for an ASEAN Community 2009-2015. Jakarta: ASEAN Secretariat, 2011.

Fatkurrohman. Isu dan Realita Konflik Kawasan. Yogyakarta: Gadjah Mada University Press, 2010. 
Fisher, Simon (ed.), Working with Conflict: Skills and Strategies for Action, United Kingdom: Zed Books, 2000.

Irsan, Abdul. Peluang dan Tantangan Diplomasi Indonesia. Jakarta: Himmah Media Utama, 2010.

Jenggis, Akhmad. 10 Isu Global di Dunia Islam. Yogyakarta: NFP Publishing, 2012.

Kaelan. Pendidikan Pancasila. Yogyakarta: Penerbit Paradigma, 2010.

Miall, Hugh, dkk. Resolusi Damai Konflik Kontemporer: Menyelesaikan, Mencegah, Melola, dan Mengubah Konflik Bersumber Politik, Sosial, Agama, dan Ras. Jakarta: Rajawali Pers, 2000.

Mulyana (Penyunting). Demokrasi dalam Budaya Lokal. Yogyakarta: Tiara Wacana, 2005.

Purba, Muhar Wahyu, dan Amir PR (ed.) Sekitar Nilai-Nilai Demokrasi pada Empat Etnis di Sulawesi Selatan. Makassar: FIK-ORNOP Sulsel dan YAPPIKA Jakarta, 2000.

Putra, Hilton Tarnama dan Eka An Aqimuddin. Mekanisme Penyelesaian Sengketa di ASEAN: Lembaga dan Proses. Yogyakarta: Graha Ilmu, 2011.

Santoso, Soewito. Sutasoma: a Study in Old Javanese Wajrayana. New Delhi: International Academy of Culture, 1975.

Siddiq, Muhammad. Demokrasi Yang Terpenjarakan: Pengamatan Tragis Seorang Analis Pemula. Yogyakarta: Gemini Publishing, 2012.

Surwandono, dan Sidiq Ahmadi. Resolusi Konflik di Dunia Islam. Yogyakarta: Graha Ilmu, 2011.

Warsito, Tulus dan Wahyuni Kartikasari. Diplomasi Kebudayaan: Konsep dan Relevansi Bagi Negara Berkembang: Studi Kasus Indonesia. Yogyakarta: Penerbit Ombak, 2007.

Winataputra, Udin S., Dasim Budimansyah. Pendidikan Kewarganegaraan dalam Perspektif Internasional: Konteks, Teori, dan Profil Pembelajaran. Bandung: Widya Aksara Press, 2012.

Zamroni. Pendidikan Demokrasi pada Masyarakat Multikultural. Yogyakarta: Gavin Kamal Utama, 2011.

\section{Artikel dalam Jurnal/Proceeding/Bahan Ajar}

Ahmad, Nora. 'Rohingya: The Lost Moslem Asia'. The Moslem World League Journal Vol. 30 .

Fithriana, Arin. Peran Indonesia melalui Regional Peace Making dalam Pencapaian ASEAN Community [Proceeding Seminar Asosiasi Ilmu Hubungan Internasional Indonesia 2012, Program Studi Hubungan Internasional Universitas Muhammadiyah Malang].

Irmawati. The Role of ASEAN in Promoting Human Rights: A Case Study of Rohingya Refugees [Proceeding International Humanitarian Action Forum 2012, Institute of International Studies (IIS) UGM]. 
Nurhayati, Ririn Tri. Assestment on the Myanmar Government's Response to the Violence in Rakhine. [Proceeding Seminar Asosiasi Ilmu Hubungan Internasional Indonesia 2012, Program Studi Hubungan Internasional Universitas Muhammadiyah Malang].

Sugito. Tantangan-Tantangan dalam Upaya Peacebuilding [Bahan Ajar] Yogyakarta: Jurusan Ilmu Hubungan Internasional Universitas Muhammadiyah Yogyakarta, 2008.

Sugito. Javanese Wisdom sebagai Nilai dalam Membentuk Sikap Partai Politik sebagai Agen Resolusi Konflik di Daerah Istimewa Yogyakarta [Jurnal Sosial dan Politik Universitas Muhammadiyah Yogyakarta].

Sugito. Bahan Ajar Powerpoint Mata Kuliah Resolusi Konflik [Bahan Ajar], Yogyakarta: Jurusan Ilmu Hubungan Internasional Universitas Muhammadiyah Yogyakarta, 2012.

Sugito. Ethnic and Internal Conflict [Bahan Ajar], Yogyakarta: Jurusan Ilmu Hubungan Internasional Universitas Muhammadiyah Yogyakarta, 2012.

Wahyudi, Yurike F. Protecting Refugess in Protracted Situations: The Case of Rohingya Refugees in Southeast Asia [Proceeding International Humanitarian Action Forum 2012, Institute of International Studies (IIS) UGM].

\section{Artikel dari Internet}

Al Jazeera. "Why is the world ignoring Myanmar's Rohingya?". [http://www.aljazeera.com/programmes/insidestory/2012/07/201272383656931979.html] diakses 17 Oktober 2012.

Genocide Watch, "Genocide Emergency: Western Myanmar, Rakhine State: The Rohingya", [http://www.genocidewatch.org/myanmar.html] diakses 20 Oktober 2012.

Indranastiti, Yoan. "Sejarah Negara Myanmar".

[http://yoanindranastiti.wordpress.com/2012/01/27/sejarah-negara-myanmar/] diakses 14 Oktober 2012.

Islam, Nurul. "Rohingya Tangled in Burma Citizenship Politics".

[http://indonesia4rohingya.org/2012/08/12/rohingya-tangled-in-burma-citizenship-politics/] diakses 16 Oktober 2012.

Pizaro, "Heru Susetyo: Muslim Rohingya Sudah Ada Sebelum Myanmar Ada" [http://www.hidayatullah.com/read/23932/26/07/2012/heru-susetyo:-muslim-rohingya-sudahada-sebelum-myanmar-ada.html] diakses 10 Oktober 2012.

Pusat Informasi dan Advokasi Rohingya Arakan, "Rohingya 101 Data dan Fakta", [http://indonesia4rohingyadotorg.files.wordpress.com/2012/08/rohingya-101-data-danfakta.pdf] diakses 14 Oktober 2012.

Saragih, Bagus BT. "SBY Reminds of Importance of 'Bhinneka Tunggal Ika"'. [http://www.thejakartapost.com/news/2012/08/02/sby-reminds-importance-bhinneka-tunggalika.html] diakses 17 Oktober 2012.

Suhardijanto, Totok. "Mengenal Etnis Rohingya dari Sudut Pandang Sejarah". [http://www.mizan.com/news_det/mengenal-etnis-rohingya-dari-sudut-pandang-sejarah.html] diakses 14 Oktober 2012. 


\section{Rekaman Audio}

Peluang Indonesia Mengambil Peran dalam Resolusi Konflik di Myanmar (Forum Group Discussion Achmad Zulfikar dan Sarah Nur Ramadhani dengan Sugito, S.IP., M.Si.)

Tercapainya Kesepakatan didasarkan oleh 3 Suara Anggota Negara (Diskusi Komisi HAM International Humanitarian Action Forum, 2012). 